\title{
MICROSOFT DAN ASUS PERLUAS KERJASAMA PELISENSIAN HAK PATEN
}

\author{
Marina Manda Sari \\ 155100046,785567835 \\ Fakultas Komputer \\ marinamandasari.student@umitra.ac.id
}

\begin{abstract}
ASUS Indonesia telah mengumumkan bahwa mulai Kami (23/11), semua notebook terbaru yang diluncurkan ke pasaran akan dilengkapi dengan sistem operasi Windows 10. Bersama dengan Microsoft, ASUS ingin mewujudkan pengalaman komputasi yang lebih inovatif melalui fitur-fitur yang ada pada sistem operasi tersebut dan notebook ASUS.
\end{abstract}

Seluruh varian notebook ASUS, mulai dari notebook premium, ultrabook dan convertible sampai ke notebook gaming, nantinya akan dilengkapi salah satu dari dua sistem operasi Windows 10, yaitu Home Edition atau Professional Edition. Tak hanya itu, notebook mainstream dan model terjangkau pun akan hadir dengan Windows 10

Kata Kunci : Microsoft dan Asus bekerja sama.

\section{A. INTRODUCTION}

ASUS Indonesia telah mengumumkan bahwa mulai Kami (23/11), semua notebook terbaru yang diluncurkan ke pasaran akan dilengkapi dengan sistem operasi Windows 10. Bersama dengan Microsoft, ASUS ingin mewujudkan pengalaman komputasi yang lebih inovatif melalui fitur-fitur yang ada 
pada sistem operasi tersebut dan notebook ASUS.

Seluruh varian notebook ASUS, mulai dari notebook premium, ultrabook dan convertible sampai ke notebook gaming, nantinya akan dilengkapi salah satu dari dua sistem operasi Windows 10, yaitu Home Edition atau Professional Edition. Tak hanya itu, notebook mainstream dan model terjangkau pun akan hadir dengan Windows 10.

Sebenarnya, ASUS sudah lama menjadi partner Microsoft dalam menghadirkan pengalaman terbaik dari sisi hardware dan software. Microsoft yakin bahwa PC merupakan perangkat utama pendukun kreativitas dan bisa mendorong pengguna untuk menghasilkan karya yang lebih inovatif. Dengan hadirnya Windows 10 di seluruh notebook ASUS, pengguna bisa memanfaatkan seluruh kemampuan Windows 10 Fall Creators Update dan menikmati perlindungan terhadap ancaman software.

Windows 10 Fall Creator Update memberikan pengguna pengalaman baru yang menyenangkan untuk menjadi kreatif. Fitur seperti Windows Ink yang memungkinkan pengguna untuk langsung menuangkan ide dan imajinasinya ke notebook.
Tidak hanya itu, pembaruan juga dilakukan pada fitur lainnya, antara lain, aplikasi foto dan video, peningkatan pada fitur gaming, keamanan dan akesesibilitas yang lebih mendalam berkat teknologi virtual reality yang disebut dengan Windows Mix Reality.

Pengguna pun tentu saja dapat menikmat fitur-fitur dan aplikasi andalan dari Microsoft yang memang sudah ada sebelumnya yakni Windows Hello dan Microsoft Edge. Pembaruan pada browser Microsoft Edge juga membuatnya semakin nyaman dan cepat ketika digunakan.

Windows 10 juga merupakan sistem operasi yang paling aman karena telah dilengkapi dengan anti virus terbaik buatan Microsoft yakni Windows Defender secara bawaan. Tidak hanya itu, OS ini juga selalu menawarkan update rutin secara terus menerus untuk melindungi pemakainya dari bermacam serangan seperti malware, virus, spyware yang terdapat di email, aplikasi, cloud, atau dari langsung dari sebuah website.

Ketika pengguna tetap konsisten untuk memperbarui sistem operasinya, mereka akan mendapatkan beragam fitur dan perlindungan keamanan (security system) terbaru. Dengan lisensi Windows original, kamu akan mendapatkan pengalaman 
terbaik dalam menggunakan Windows 10. Update akan dilakukan secara otomatis dan gratis. Adapun dukungan teknis dari Microsoft akan tersedia selama 24 jam non stop via telepon, live chat ataupun layanan dukungan lainnya.

\section{B. CONTENT}

Sebenarnya, ASUS sudah lama menjadi partner Microsoft dalam menghadirkan pengalaman terbaik dari sisi hardware dan software. Microsoft yakin bahwa PC merupakan perangkat utama pendukun kreativitas dan bisa mendorong pengguna untuk menghasilkan karya yang lebih inovatif. Dengan hadirnya Windows 10 di seluruh notebook ASUS, pengguna bisa memanfaatkan seluruh kemampuan Windows 10 Fall Creators Update dan menikmati perlindungan terhadap ancaman software.

\section{CONCLUSION}

Sebenarnya, ASUS sudah lama menjadi partner Microsoft dalam menghadirkan pengalaman terbaik dari sisi hardware dan software. Microsoft yakin bahwa PC merupakan perangkat utama pendukun kreativitas dan bisa mendorong pengguna untuk menghasilkan karya yang lebih inovatif. Dengan hadirnya Windows 10 di seluruh notebook ASUS, pengguna bisa memanfaatkan seluruh kemampuan Windows 10 Fall Creators Update dan menikmati perlindungan terhadap ancaman software.

Windows 10 Fall Creator Update memberikan pengguna pengalaman baru yang menyenangkan untuk menjadi kreatif. Fitur seperti Windows Ink yang memungkinkan pengguna untuk langsung menuangkan ide dan imajinasinya ke notebook. Tidak hanya itu, pembaruan juga dilakukan pada fitur lainnya, antara lain, aplikasi foto dan video, peningkatan pada fitur gaming, keamanan dan akesesibilitas yang lebih mendalam berkat teknologi virtual reality yang disebut dengan Windows Mix Reality.

Pengguna pun tentu saja dapat menikmat fitur-fitur dan aplikasi andalan dari Microsoft yang memang sudah ada sebelumnya yakni Windows Hello dan Microsoft Edge. Pembaruan pada browser Microsoft Edge juga membuatnya semakin nyaman dan cepat ketika digunakan.

\section{DISCUSSION}

"ASUS memastikan kalau mulai saat ini seluruh notebook yang akan dirilis baik itu kelas premium, gaming, convertible, dan ultrabook akan langsung menjalankan sistem operasi WIndows 10 asli. Maka dari itu ke depannya sudah tidak akan ada lagi notebook ASUS resmi yang dijual dengan DOS atau Endless OS" 
Dari sisi konsumer tentu saja hal ini sangat menguntungkan karena tidak perlu lagi bingung maupun susah payah untuk install sistem operasi. Dengan menggunakan Windows 10 asli, notebook juga akan lebih terjaga karena akan terus mendapatkan update untuk mengikuti perkembangan era khususnya para pembuat konten.

\section{E. REFERENCE}

[1] O. M. Febriani and A. S. Putra, "Sistem Informasi Monitoring Inventori Barang Pada Balai Riset Standardisasi Industri Bandar Lampung," J. Inform., vol. 13, no. 1, pp. 90-98, 2014.

[2] A. S. Putra, "Paperplain: Execution Fundamental Create Application With Borland Delphi 7.0 University Of Mitra Indonesia," 2018.

[3] A. S. Putra, "2018 Artikel Struktur Data, Audit Dan Jaringan Komputer," 2018.

[4] A. S. Putra, "ALIAS 
MANAGER USED IN DATABASE DESKTOP STUDI CASE DB DEMOS."

[5] A. S. Putra, "COMPREHENSIVE SET OF PROFESSIONAL FOR DISTRIBUTE COMPUTING."

[6] A. S. Putra, "DATA ORIENTED RECOGNITION IN BORLAND DELPHI 7.0."

[7] A. S. Putra, "EMBARCADERO DELPHI XE 2 IN GPUPOWERED FIREMONKEY APPLICATION."

[8] A. S. Putra, "HAK ATAS KEKAYAAN INTELEKTUAL DALAM DUNIA TEKNOLOGY BERBASIS REVOLUSI INDUSTRI 4.0.”

[9] A. S. Putra, "IMPLEMENTASI PERATURAN

PERUNDANGAN UU. NO 31

TAHUN 2000 TENTANG DESAIN INDUSTRI BERBASIS INFORMATION TECHNOLOGY."

[10] A. S. Putra, "IMPLEMENTATION OF PARADOX DBASE."

[11] A. S. Putra, "IMPLEMENTATION OF TRADE SECRET CASE STUDY SAMSUNG MOBILE PHONE."

[12] A. S. Putra, "IMPLEMENTATION PATENT FOR APPLICATION WEB BASED CASE STUDI WWW. PUBLIKLAMPUNG. COM."

A. S. Putra, "IMPLEMENTATION SYSTEM FIRST TO INVENT IN DIGITALLY INDUSTRY."

[14] A. S. Putra, "MANUAL
REPORT \& INTEGRATED DEVELOPMENT

ENVIRONMENT BORLAND DELPHI 7.0."

[15] A. S. Putra, "PATENT AS RELEVAN SUPPORT RESEARCH."

[16] A. S. Putra, "PATENT FOR RESEARCH STUDY CASE OF APPLE. Inc."

[17] A. S. Putra, "PATENT PROTECTION FOR APPLICATION INVENT."

[18] A. S. Putra, "QUICK REPORT IN PROGRAMMING."

[19] A. S. Putra, "REVIEW CIRCUIT LAYOUT COMPONENT

REQUIREMENT ON ASUS NOTEBOOK."

[20] A. S. Putra, "REVIEW TRADEMARK PATENT FOR INDUSTRIAL TECHNOLOGY BASED 4.0."

[21] A. S. Putra, "TOOLBAR COMPONENT PALLETTE IN OBJECT ORIENTED PROGRAMMING."

[22] A. S. Putra, "WORKING DIRECTORY SET FOR PARADOX 7."

[23] A. S. Putra, "ZQUERY CONNECTION

IMPLEMENTED

PROGRAMMING STUDI CASE PT. BANK BCA Tbk."

[24] A. S. Putra, D. R. Aryanti, and I. Hartati, "Metode SAW (Simple Additive Weighting) sebagai Sistem Pendukung Keputusan Guru Berprestasi (Studi Kasus: SMK Global Surya)," in Prosiding Seminar Nasional Darmajaya, 2018, vol. 
1, no. 1, pp. 85-97.

[25] A. S. Putra and O. M. Febriani, "Knowledge Management Online Application in PDAM Lampung Province," in Prosiding International conference on Information Technology and Business (ICITB), 2018, pp. 181-187.

[26] A. S. Putra, O. M. Febriani, and B. Bachry, "Implementasi Genetic Fuzzy System Untuk Mengidentifikasi Hasil Curian Kendaraan Bermotor Di Polda Lampung," SIMADA (Jurnal Sist. Inf. dan Manaj. Basis Data), vol. 1, no. 1, pp. 21-30, 2018.

[27] A. S. Putra, H. Sukri, and K. Zuhri, "Sistem Monitoring Realtime Jaringan Irigasi Desa (JIDES) Dengan Konsep Jaringan Sensor Nirkabel," IJEIS (Indonesian J. Electron. Instrum. Syst., vol. 8, no. 2, pp. 221-232.

[28] D. P. Sari, O. M. Febriani, and A. S. Putra, "Perancangan Sistem Informasi SDM Berprestasi pada SD Global Surya," in Prosiding Seminar Nasional Darmajaya, 2018, vol. 1, no. 1, pp. 289-294. 